\title{
Prolificacy genes in sheep: the French genetic programmes
}

\author{
P. Mulsant ${ }^{1}$, F. Lecerf ${ }^{1}$, S. Fabre ${ }^{2}$, L. Bodin 3 , J. Thimonier ${ }^{4}$, \\ P. Monget ${ }^{2}$, I. Lanneluc ${ }^{1}$, D. Monniaux ${ }^{2}$, J. Teyssier ${ }^{4}$ \\ and $\mathrm{J}-\mathrm{M}$. Elsen ${ }^{3}$
}

'INRA, Laboratoire de Génétique Cellulaire, BP 27, 31326 Castanet-Tolosan, France; ${ }^{2}$ INRA, Physiologie de la Reproduction et des Comportements, UMR 6073 INRA-CNRS-Université François Rabelais, 37380 Nouzilly, France; ${ }^{3}$ INRA, Station d'Amélioration Génétique des Animaux, BP 27, 37326 Castanet-Tolosan, France; and ${ }^{4}$ UMR INRA - ENSAM - CIRAD, Elevage des Ruminants en Régions Chaudes, 2 place Viala, 34060 Montpellier Cedex 02, France

\begin{abstract}
It has been demonstrated that variations in litter size or ovulation rate in different breeds of sheep can be associated with the segregation of several major genes. This set of natural mutants constitutes a valuable resource to determine key points in the biochemical pathways controlling the development of ovarian follicles. The French genetic programmes were devised to identify two of these genes: the Booroola $(F e c B)$ and Lacaune genes. The $F e c B$ prolific mutation corresponds to a non-conservative mutation (Q249R) in the intracellular kinase-signalling domain of the bone morphogenetic protein receptor type IB (BMPR-IB) gene. The Lacaune gene is situated on ovine chromosome 11. Positional cloning is currently in progress to identify the relevant gene and mutation. A similar approach, limited to linkage testing of candidate genes, is proposed to classify the different prolificacy genes in sheep.
\end{abstract}

\section{Introduction}

The intricate mechanisms that control ovulation rate in female mammals are still poorly understood. In this respect sheep are considered as a model species, as a large genetic variation in prolificacy has been reported and the segregation of several major genes affecting ovulation rate and litter size has been demonstrated (Fahmi, 1996). In particular, in the Australian Booroola Merino sheep, the hyperprolific phenotype is due to the action of a single autosomal gene $(F e c B)$, which influences the number of ovulations per oestrous cycle in the ewe. In a breed of low prolificacy, for example the Merino, ewes that are homozygous $\left(\mathrm{Fec} B^{B} / \mathrm{Fec} B^{B}\right)$, heterozygous $\left(\mathrm{FecB} B / F e c B^{+}\right)$and non-carriers $\left(F e C B^{+} / F e c B^{+}\right)$of the $F e c B^{B}$ Booroola mutation can be segregated on the basis of ovulation rate recordings of five or more, three or four and one or two, respectively (Davis et al., 1982; Piper and Bindon, 1982). The effect of major genes has since been reported in different breeds of sheep, including Icelandic, Javanese, Olkuska, Cambridge, Belclare, Lacaune and Woodlands breeds, as reviewed by 
Montgomery et al. (2001), and extensive programmes were set up in different laboratories to study the mechanisms underlying the observed high ovulation rates and to identify the genes and mutations involved. The French genetic programmes focused on the FecB (Booroola) and Lacaune genes. The purpose of this review is to present the main results of these programmes and to indicate how similar genetic studies on the other suspected mutations could be implemented to detect key genes in the regulation of ovarian development.

\section{The Booroola FecB gene}

A total of 13 Booroola-carrier rams (or their semen) were imported from Australia, New Zealand and the UK between 1981 and 1989. Introgression schemes of the prolific $\mathrm{Fec} B^{B}$ allele (referred to as $B$ thereafter for the sake of simplicity) were developed first in the non-prolific Mérinos d'Arles breed, and later in the prolific Romanov breed (Bomarov, 1991). The introgression of the $B$ allele in Mérinos d'Arles was performed using a classical backcrossing scheme, in which the progeny of all males was tested and only rams classified as heterozygous on this basis contribute to the establishment of the next backcross generation. Introgression in the Romanov breed used an original scheme in which at each generation both $\mathrm{B} /+$ and $+1+$ males were crossed with purebred Romanov females, and putative heterozygous sires were identified by progeny testing on Mérinos d'Arles ewes at late stages. The introgression crosses yielded well-characterized $\mathrm{B} /+$ and $+1+$ offspring for physiological studies and comparison of breeding performances. In addition, ewes were characterized by their ovulation rates and their heterozygous sires formed a suitable backcross population for genetic studies, with the advantage of a narrow distribution of ovulation rates of the recipient Mérinos d'Arles ewes, which diminished the risk of erroneous classification of progeny ewes.

\section{Genetic mapping}

As the genetic analysis began in the mid-1980s, the few markers available at that time, protein markers, blood groups and restriction fragment length polymorphisms, were used and there was no evidence for a marker linked to the Fec $B$ locus. The demonstration by Montgomery et al. (1993) of linkage between FecB and the EGF and SPP1 loci focused the analysis on the relevant sheep chromosomal region (OAR6, Montgomery et al., 1994). A high conservation was observed between this region of ovine (or bovine) chromosome 6 and the 4q21-24 part of human chromosome 4 (Lanneluc et al., 1996; Lord et al., 1996), allowing efficient comparative mapping and the development of a chromosome jumping strategy. Different ruminant large-insert (bacterial or yeast artificial chromosomes, BAC or $Y A C$, respectively) libraries were thus screened with (i) microsatellites of bovine chromosome 6 and (ii) comparative anchored tagged sequences corresponding to genes located on human chromosome 4q21-24. Genetic markers were developed in the isolated BACs or YACs, either in the form of microsatellites or single nucleotide polymorphisms (SNPs). Linkage with the $\mathrm{Fec} B$ locus was tested on 31 half-sib backcross families from heterozygous $\mathrm{B} /+$ sires as indicated above (400 informative meioses for $F e c B$ ). The $F e c B$ locus was found to be situated between ETL-1 and the microsatellite Bulge5 isolated from a bovine YAC screened with $P D H A 2$-specific primers. This reduced the regional localization of $F e c B$ to a 2 centimorgan (CM) interval, corresponding to a 7 centiray interval on the GB4 human irradiation map.

\section{Positional cloning}

Genotyping genes from the ETL-1/PDHA2 interval, and the derived markers, allowed definition of a chromosomal region with no recombinants with $F e c B$. This region was included in 


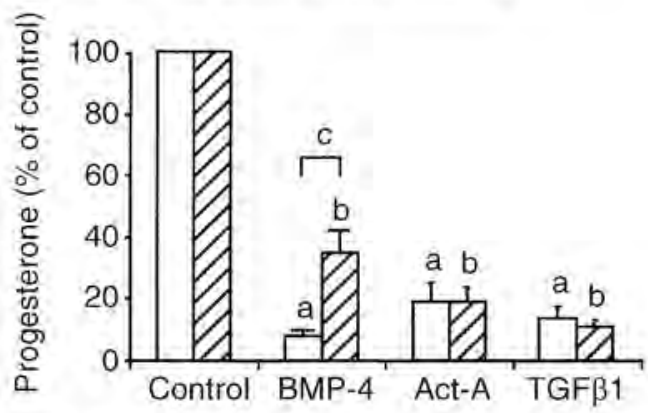

Fig. 1. Effect of the Booroola mutation on responsiveness of granulosa cells to bone morphogenetic protein 4 (BMP-4), activin A and transforming growth factor $\beta 1$ (TGF $\beta 1$ ) in vitro. Granulosa cells were collected from wild-type ( $\square$ ) and Booroola (घa) small antrál follicles (1-3 $\mathrm{mm}$ in diameter) and cultured for $96 \mathrm{~h}$ in serum-free conditions in the presence or absence (control) of $50 \mathrm{ng} \mathrm{ml}^{-1} \mathrm{BMP}-4$, activin A (Act-A) or TGFB1 in the culture medium. Results are expressed as progesterone secretion by the granulosa cells between 48 and $96 \mathrm{~h}$ of culture. Values are expressed as percentages (mean \pm SEM) of progesterone secreted by cells in the absence of ligand, ${ }^{\circ} P<0.01$, treated versus control (wild-type); ${ }^{\text {b }} P<0.01$, treated versus control (Booroola); ${ }^{\circ} P<0.01$, Booroola versus wild-type.

a contig of four ovine BACs and contained two identified genes, bone morphogenetic protein receptor type I (BMPR-IB) and UNC5C (Mulsant et al., 2001). The BMPR-IB gene was the only gene situated in this contig and expressed in ovine ovaries. Thus, it was considered as a positional candidate for $F e c B$ and was studied in more detail. Sequence comparison of sheep ovarian BMPR-IB cDNAs from $+1+$ and $B / B$ ewes identified a point mutation in $B / B$ animals, which substitutes the glutamine present in the wild-type sequence with an arginine (Mulsant et al., 2001). The same Q249R mutation was independently identified in Booroola sheep by Souza et al. (2001) and Wilson et al. (2001), and was later found to be present too in prolific animals from Garole and Javanese breeds (Davis et al., 2002). Shortly after the first identification of the Q249R mutation, it was demonstrated that the BMP system was expressed in rat ovaries and affected steroid synthesis of granulosa cells (Shimasaki et al., 1999). The importance of BMPs in the ovary was further emphasized by the discovery that mutations in the BMP15 gene affected prolificacy in Inverdale and Hanna sheep (Galloway et al., 2000).

\section{Mutation effects}

The Q249R mutation is situated in the intracellular kinase-signalling domain, but does not appear to affect previously identified critical amino acids. Molecular modelling of ovine BMPR-IB using the recently solved transforming growth factor $\beta$ receptor-FK506 binding protein (TGFBR-1-FKBP12) complex as a substrate indicated only a possible reinforcement of the interaction between FKBP12 and the receptor. The physiological role of BMPR-1B in ovine granulosa cells was investigated by studying the effects of recombinant GDF- 5 or BMP4, two ligands known to exert their actions specifically through type I BMP receptors. Ovarian granulosa cells from $B / B$ follicles of $1-3 \mathrm{~mm}$ in diameter were less responsive than granulosa cells from $+1+$ follicles of $1-3 \mathrm{~mm}$ in diameter to the inhibitory effects of both of these ligands on progesterone secretion (Mulsant et al., 2001). Control experiments with TGF $\beta-1$ and activin A, presumed to act independently of BMPR-IB, showed the same inhibitory effects on progesterone secretion of cells of both $+1+$ and B/B genotypes (Fig. 1, Fabre et al., in press). 


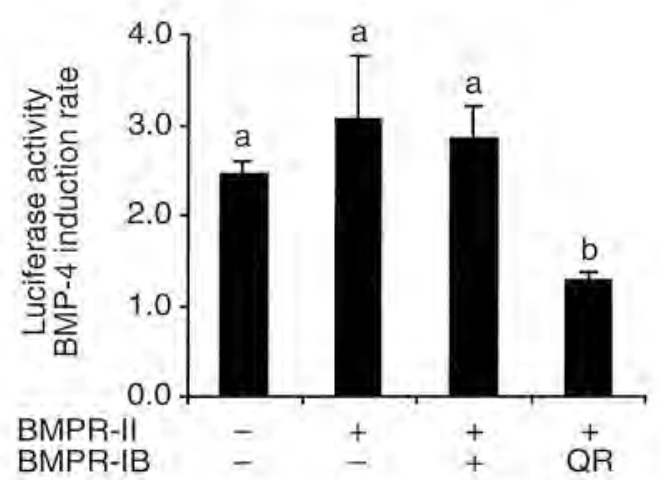

Fig. 2. Effect of the Booroola mutation on bone morphogenetic protein receptor IB (BMPR-IB) signalling activity. HEK-293 cells growing in 10\% fetal calf serum were transiently transfected with the 12-GCCG-lux reporter construct and different combinations of plasmids expressing human BMPR-1I and ovine BMPR-IB with or without the Q249R mutation (QR), After transfection, cells were cultured for $24 \mathrm{~h}$ in serum-free conditions in the absence (basal) or presence of $100 \mathrm{ng}$ bone morphogenetic protein $4(\mathrm{BMP}-4) \mathrm{ml}^{-1}$ before luciferase assays. Data are expressed as the induction rate of luciferase activity (mean \pm SEM) by BMP-4. Values with a different letter are significantly different $(P<0.01)$.

This finding indicates that the defect present in Booroola sheep specifically affects the BMP but not TGF $\beta$ pathway. Cloned + and B BMPR-IB CDNA sequences in eukaryotic expression vectors were used to confirm a functional difference between the wild-type and mutant forms of BMPR-IB. Human 293 cells were transfected by these constructions, together with a plasmid expressing human BMPR-II and a BMP-specific Smad response element in front of the luciferase gene. Preliminary experiments show a diminished response to BMP-4 of cells transfected with the mutant form of BMPR-IB (Fig, 2, Fabre et al., in press). Taken together the results of these studies in vitro indicate that the Q249R mutation of BMPR-IB induces a partial alteration in the responsiveness to inhibitory effects of BMPs. It is interesting to note that the reduction of BMP15 mature peptide concentration in heterozygous Fec X ewes has a similar effect on ovulation rate as the Booroola $F e c B$ mutation. All of these arguments indicate that in both $F e c X$ and $F e c B$ mutant genotypes, a partial loss of concentration or activity, respectively, of factors of the BMP family that impede premature luteinization of follicles might lead to an advancement of their final maturation and an increase in ovulation rate. The mechanism leading to this increase in ovulation rate remains unknown.

Interestingly, female mice lacking BmprlB display clear skeletal defects, have normal ovulation rates and are infertile as a result of a number of ovarian and endometrial defects ( $\mathrm{Yi}$ et al., 2001). All of these phenotypic characteristics clearly distinguish BmprlB-deficient mice from Booroola ewes, It can be argued that part of the observed difference is speciesspecific. In particular, such species differences have been observed in females that are heterozygous for the BMP15 gene. In heterozygous FecX ewes, this genetic defect leads to an increase in ovulation rate, whereas Bmp $15+1$-female mice present a small decrease in prolificacy (Galloway et al., 2000; Yan et al., 2001). Another interpretation would be that the complete invalidation of $B M P R-I B$ gene would not have the same consequences as a point mutation, as previously described for $p 53$ (Blackburn and Jerry, 2002). Further experiments are required to determine the physiological ligands of BMPR-IB in the ovary, how the BMP system modulates ovulation rate and to elucidate the effect of the $F e c B$ mutation on the receptor. 


\section{The Lacaune gene}

The Lacaune breed with 1.2 million ewes is the main French sheep breed. In 1975, an onfarm selection scheme was implemented to improve prolificacy. The large and fast selection response for prolificacy together with several other indications supported non-polygenic inheritance of prolificacy in this selected population. A specific backcross programme aiming to observe possible gene segregation was devised to prove the existence of a major gene segregating in the Lacaune population (Bodin et al., 1998). The distributions of ovulation rates of backcross progeny ewes were consistent with the hypothesis of the segregation of two co-dominant alleles of a major autosomal gene, $L$ (inducing higher ovulation) and + (Bodin et al., 1998, 2002). The difference between homozygous non-carriers and heterozygous ewes was about one ovulation on the observed scale and 2.2 standard deviations on the underlying scale. Crosses between presumed heterozygous carrier animals effectively yielded three classes of progeny ewe, the mean ovulation rate of putative L/L females ranging between five and seven.

\section{Genetic mapping}

The above-mentioned progeny analysis identified 10 sires as being heterozygous $\mathrm{L} /+$ (the three founders and seven $F_{1}$ male offspring). These animals and their progeny ewes classified as $\mathrm{L} /+$ or $+1+$ were used for genetic analysis. It was confirmed that the FecB Booroola and FecX Inverdale mutations were absent in all of the heterozygous males. A full genome scan was performed and linkage was demonstrated between Lacaune and markers of ovine chromosome 11. Multipoint analysis located the Lacaune locus between microsatellite markers BM17132 and CSSM15, in a 5 cM interval (Lecerf et al., 2002). In addition, a single haplotype was found to be associated with prolificacy in the different families, which supports the contention that a unique mutation segregates in this breed. This region of sheep chromosome 11 has been shown to correspond to human chromosome 17 and bovine chromosome 19 . However, changes in gene order have been demonstrated between the orthologous bovine chromosome 19 and human chromosome 17, near the probable region of the Lacaune locus (Yang et al., 1998). Additional genotyping is in progress to reduce the localization interval of the Lacaune locus, precisely define the human orthologous region and screen candidate genes in this region.

\section{Future prospects}

Mutations that strongly influence ovulation rate and prolificacy have been demonstrated in BMP15 (Hanna, Inverdale) and BMPR-IB (Booroola, Garole, Javanese) genes. The Lacaune locus maps to chromosome 11 and is different from the BMP15 and BMPR-IB loci. The Woodlands FecX2 gene appears to be imprinted and, therefore, is likely to correspond to a fourth gene. The identification of the Booroola and Inverdale mutations made it feasible to perform mutation-specific genotyping with no pedigree information. DNA tests in eight different prolific sheep allowed Davis et al. (2002) to demonstrate the presence of the Booroola mutation in Garole and Javanese thin-tailed sheep, and to confirm the association of the mutation with prolificacy. Whether the other reported or suspected mutations represent new alleles of the same genes or affect a different set of genes is not known. In the absence of a simple biochemical or phenotypic test, sequence analysis and genetic mapping approaches can be combined to address these questions and classify the different genes and mutations involved. Whenever possible, a linkage test, preferentially based on a backcross scheme from 
presumed heterozygous sires, will have two important advantages: (i) it does not necessitate the previous identification of a causal mutation, as it requires only close genetic markers (for example, it is possible to test the involvement of the Lacaune locus in prolificacy in other breeds), and (ii) the same linkage analysis tests both exclusion and close linkage between a putative gene affecting prolificacy and a candidate gene, thus limiting further sequence analysis to a candidate gene effectively shown to be associated with prolificacy. Providing that two close flanking genetic markers are used, such a genetic mapping of candidate genes will require only from 20 to 30 informative, that is with low or high ovulation rate, progeny female animals.

\section{Conclusion}

The identification of the Booroola and Inverdale mutations emphasized the key role of BMPs and their receptors in the ovary. The other unidentified prolificacy genes represent an extremely valuable resource to determine additional key factors in BMP signalling pathways or in other biochemical networks controlling the development of the ovarian follicle.

The authors thank all the members of the French Bomarov group. The reported work was supported by grants from INRA, region Midi-Pyrénées and the European Union.

\section{References}

Blackburn AC and Jerry DJ (2002) Knockout and transgenic mice of Trp53: what have we learned of $p 53$ in breast cancer? Breast Cancer Research 4 101-111

Bodin L, Elsen IM, Poivey JP, San Cristobal-Gaudy M, Belloc JP and Eychenne F (1998) Hyper-prolificacy in the French Lacaune sheep breed; a possible major gene. In Proceedings of the $6^{\text {th }}$ WCGALP, Armidale 27 11-14

Bodin L, San Cristobal M, Lecerf F, Mulsant P, Bibé B, Lajous D, Belloc JP, Eychenne F and Elsen JM (2002) Segregation of a major gene influencing ovulation in progeny of Lacaune meat sheep Genetics Selection Evolution 34 447-464

Bomarov (1991) The Booroola gene in France. In: Major Genes for Reproduction in Sheep pp 47-51 Eds IM Elsen, L Bodin and J Thimonier. INRA, Paris

Davis GH, Montgomery GW, Allison AJ, Kelly RW and Bray AR (1982) Segregation of a major gene influencing fecundity in progeny of Booroola sheep New Zealand Journal of Agricultural Research 25 525-529

Davis GH, Galloway SM, Ross IK et al. (2002) DNA tests in prolific sheep from eight countries provide new evidence on origin of the Booroola ( $\mathrm{fec} B$ ) mutation Biology of Reproduction 66 1869-1874

Fabre S, Pierre A, Pisselet C, Mulsant P, Lecerf F, Pohl J, Monget $\mathbf{P}$ and Monniaux D The Booroola mutation in sheep is associated with an alteration of the bone morphogenetic protein receptor-1B functionality Journal of Endocrinology (in press)

Fahmi MH (1996) Prolific Sheep p 542. CAB International, Oxon
Galloway SM, McNatty KP, Cambridge LM et al. (2000) Mutations in an oocyte-derived growth factor gene (BMP15) cause increased ovulation rate and infertility in a dosage-sensitive manner Nalure Genetics 25 279-283

Lanneluc I, Mulsant P, Saïdi-Mehtar N and Elsen IM (1996) Synteny conservation between part of human chromosome $4 \mathrm{q}$ and bovine and ovine chromosomes 6 Cytogenetics and Cell Cenetics 72 212-214

Lecerf F, Mulsant P, Elsen JM and Bodin L (2002) LoCalisation and mapping of a major gene controlling ovulation rate in Lacaune sheep. In Proceedings of the $7^{\text {th }}$ WCGALP, Montpellier $30753-756$

Lord EA, Lumsden JM, Dodds KG et al. (1996) The linkage map of sheep chromosome 6 compared with orthologous regions in other species Mammalian Genome 7 373-376

Montgomery GW, Crawford AM, Penty JM et al. (1993) The ovine Booroola fecundity gene (FecB) is linked to markers from a region of chromosome $4 q$ Nature Genetics 4 410-414

Montgomery GW, Lord EA, Penty JM, Dodds KG, Broad TE, Cambridge LM, Sunden SLF, Stone RT and Crawford AM (1994) The Booroola fecundity (FecB) gene maps to sheep chromosome 6 Genomics 22 $148-153$

Montgomery GW, Galloway SM, Davis GH and McNatty KP (2001) Genes controlling ovulation rate in sheep Reproduction 121 843-852

Mulsant P, Lecerf F, Fabre S et al. (2001) Mutation in bone morphogenetic protein receptor $1 \mathrm{~B}$ is associated with increased ovulation rate in Booroola 
Mérino ewes Proceedings National Academy of $5 \mathrm{ci}$ ences USA 98 5104-5109

Piper LR and Bindon BM (1982) The Booroola Merino and the performance of medium non-Peppin crosses at Armidale. In The Booroola Merino pp 9-20 Eds LR Piper, BM Bindon and RD Nethery. CSIRO, Melbourne

Shimasaki S, Zachow RJ, Li D, Kim H, lemura S, Ueno N, Sampath K, Chang RJ and Erickson CK (1999) A functional bone morphogenetic protein system in the ovary Proceedings National Academy of Sciences USA $967282-7287$

Souza CJH, MacDougall C, Campbell BK, McNeilly AS and Baird DT (2001) The Booroola (FecB) phenotype is associated with a mutation in the bone morphogenetic receptor type 1B (BMPRTB) gene fournal of Endocrinalogy $169 \mathrm{R} 1-\mathrm{R} 6$

Wilson T, Wu XY, Juengel JL et al. (2001) Highly prolific
Booroola sheep have a mutation in the intracellular kinase domain of bone morphogenetic protein $1 \mathrm{~B}$ receptor (ALK-6) that is expressed in both oocytes and granulosa cells Biology of Reproduction 64 12251235

Yan C, Wang P, DeMayo J et al. (2001) Synergistic roles of bone morphogenetic protein 15 and growth differentiation factor 9 in ovarian function Molecular Endocrinology $15854-866$

Yang YP, Rexroad CE, $3^{\text {rd }}$, Schlapfer J and Womack JE (1998) An integrated radiation hybrid map of bovine chromosome 19 and ordered comparative mapping with human chromosome 17 Genomics 48 93-99

Vi SE, LaPolt PS, Yoon BS, Chen JYC, Lu JKH and Lyons KM (2001) The type I BMP receptor BmprlB is essential for female reproductive function Proceedings National Academy of Sciences USA 98 79947999 